\title{
Removal of Nitrate by Asymmetric Capacitive Deionization
}

Julio J. Lado ${ }^{\mathrm{a}, \mathrm{b}}$, Rodolfo E. Pérez-Roa ${ }^{\mathrm{c}}$, Jesse J. Wouters ${ }^{\mathrm{c}}$, M. Isabel Tejedor-Tejedor ${ }^{\mathrm{c}}$ Cade Federspill ${ }^{\mathrm{c}}$, Juan M. Ortiz ${ }^{\mathrm{a}}$ and Marc A. Anderson ${ }^{\mathrm{b}, \mathrm{c}}$

${ }^{a}$ Madrid Institute for Advanced Studies, IMDEA Water. Scientific-Technological Park of Alcalá, Madrid 28805, Spain.

${ }^{b}$ Madrid Institute for Advanced Studies, IMDEA Energy, (Electrochemical Processes Unit), 28933 Móstoles, Madrid, Spain.

${ }^{c}$ Environmental Chemistry and Technology Program (EC\&T), University of WisconsinMadison, Madison, Wisconsin 53706, USA.

Corresponding Author:

Julio J. Lado

Madrid Institute for Advanced Studies, IMDEA Energy

Electrochemical Processes Unit

Avda. Ramón de la Sagra 3. Parque Tecnológico de Móstoles

28935 Móstoles (Madrid), Spain

Telephone: +34917371120

E-mail: julio.lado@imdea.org 


\begin{abstract}
Contamination of groundwater with nitrates is a major concern, especially for areas relying on this as a drinking water source. In this work, a capacitive deionization (CDI) system equipped with carbon electrodes coated with different metal oxides was studied to determine its ability to reduce nitrate concentrations. Results performed in a three-electrode cell were used as a proof of concept and demonstrated that coated electrodes had higher nitrate removal than that of uncoated electrodes, likely because of a reduction in hydrophobicity and an increase in surface area provided by the metal oxides. Moreover, tests using different electrolytes $\left(\mathrm{NaNO}_{3}\right.$ and $\left.\mathrm{Ca}\left(\mathrm{NO}_{3}\right)_{2}\right)$ revealed similar nitrate removal values, although different electrosorption patterns were observed for $\mathrm{Na}^{+}$and $\mathrm{Ca}^{2+}$. Furthermore, an operational mode based on a multistep approach showed that nitrates could be removed below regulatory limits while reducing the volume of waste brine. A larger, eight-cell flow CDI reactor was also tested. The results from this reactor showed that the cell potential, as well as the ion being removed from a multicomponent solution $\left(\mathrm{Ca}^{2+}, \mathrm{Na}^{+}, \mathrm{Cl}^{-}, \mathrm{NO}_{3}{ }^{-}\right)$influence electrosorption kinetics. Different adsorption mechanisms based on ion charge/size/electrode affinity are discussed, possibly leading to a methodology for preferentially removing certain ions by CDI technology.
\end{abstract}

Keywords: Nitrate removal; capacitive deionization; asymmetric CDI; ion selective removal; oxide-coated electrodes. 


\section{Introduction}

Groundwater, considered the most extracted resource on Earth [1], provides between $25 \%$ to $40 \%$ of the world's drinking water [2]. Contamination by certain ions such as fluoride [3], perchlorate [4] or nitrate [3] is a threat to the availability of affordable potable water. In particular, nitrate represents one of the most serious problems due to its intensive application as a fertilizer and its high water solubility $[5,6]$. Considering its low adsorption affinity in different kinds of soils, nitrate also appears highly likely to leach into groundwater wells and reservoirs [7]. Its adverse health effects include its reduction into nitrite, which subsequently reduces hemoglobin to methemoglobin and alters the oxygen transport capacity within blood cells ('blue baby' syndrome) [6], as well as its potential link with several kinds of cancer due to its ability to form nitrosamines $[5,8,9]$ when ingested in high concentrations. Moreover, from an environmental standpoint, the presence of nitrate in water bodies such as rivers or lakes may lead to eutrophication. Such increase in the algae population depletes dissolved oxygen in water, increasing the risk of death in certain aquatic organisms [6]. Based on these considerations, organizations such as the World Health Organization (WHO) or the Environmental Protection Agency (U.S. EPA) have set a maximum concentration limit (MCL) for nitrate in drinking water

of $10 \mathrm{mg} \mathrm{L}^{-1}$ nitrogen-basis (45 $\mathrm{mg} \mathrm{L}^{-1}$ of nitrate) $[3,5,10]$. Therefore, contaminated groundwater wells used as the primary source of drinking water require treatment to achieve minimum health standards.

Current technologies for nitrate removal are typically divided into biological processes and physico-chemical treatments. Biological denitrification, a popular alternative in municipal wastewater treatment, has the advantage of being low cost, but the disadvantages of needing large-scale installation, having slow ion removal kinetics and a high sensitivity to $\mathrm{pH}$, temperature and the presence of other toxic compounds $[6,11]$. As for physical-chemical processes, ion exchange (IX) is the most widely employed treatment and frequently employed in wells, since it is cost effective for small-scale applications, as well as simple to operate and 
monitor [6]. Nevertheless, IX requires the introduction of external $\mathrm{NaCl}$ to exchange ions in a 1:1 basis with nitrate, which may affect water quality in areas with already high nitrate concentrations. Membrane-based technologies such as reverse osmosis (RO), nanofiltration (NF) or electrodyalisis (ED) have also been shown to effectively remove nitrate ions $[12,13]$. However, the high energy demand required to provide either high pressures or voltages, along with the reduction of ion removal efficiency when treating brackish waters $\left(2000-5000 \mathrm{mg} \mathrm{L}^{-1}\right.$ in salt concentration), may limit the use of these technologies $[3,6,14]$.

Capacitive Deionization (CDI) is an emerging water desalination technology that is based on the electrosorption of ions on porous electrodes by applying low potentials (typically below $1.5 \mathrm{~V})[15-17]$. The low voltages used in this process along with the possibility of retrieving part of the energy employed during the sorption of ions $[18,19]$ may lead to lower energy consumption [20]. Furthermore, no additional chemicals are required in the CDI process and high water recoveries can be obtained [21]. To date, CDI applications have been largely focused on brackish water desalination [17, 22-24], but recent research has shown its applicability for removing ions such as nitrate [14], sulfate [25, 26], fluoride [3], as well as sodium and chloride. CDI has also been suggested for the selective removal of nitrate $[3,27]$ using either nitrateselective composite carbon electrodes or by controlling the applied current $[14,28]$. While these studies have shown that CDI may be a new means of removing nitrate from groundwater, aspects such as ion removal mechanisms/patterns or the occurrence of faradaic reactions have not been thoroughly addressed.

In this work, low surface area carbons coated with different metal oxides $\left(\mathrm{SiO}_{2}\right.$ on the cathode and $\mathrm{Al}_{2} \mathrm{O}_{3}$ on the anode) were employed in an asymmetric CDI cell configuration for removing nitrate ions. The choice of metal oxides was based on differences in their zeta potentials (surface charges) in an aqueous environment, where the $\mathrm{SiO}_{2}$ particles will be negative above $\mathrm{pH}$ 3 and the $\mathrm{Al}_{2} \mathrm{O}_{3}$ positive below $\mathrm{pH}$ 9. The different surface charge of the oxides, when no external potentials are applied to the electrodes, should reduce the co-ion desorption during the adsorption 
step and minimize the counter-ion electrosorption (crossover) during electrode regeneration (i.e., ion desorption) [29]. Additional benefits of using oxide-coated electrode composites in CDI have also been mentioned [29-33] and include: (1) the large surface site densities of oxide composite electrodes [29, 30], (2) the reduction of hydrophobicity of the carbon substrate $[29,34]$ that leads to improved ion transport and adsorption kinetics [35], and (3) an increase in the charge efficiency due to the asymmetric natural surface potential associated with these oxides [33, 36$38]$

Initial experiments described in this study were based on a three-electrode cell configuration using nitrate-based salts $\left(\mathrm{NaNO}_{3}\right.$ or $\left.\mathrm{Ca}\left(\mathrm{NO}_{3}\right)_{2}\right)$. These small-scale tests were conducted as a "proof of concept" to evaluate the net effect of the metal oxide coatings on nitrate removal, and to assess the ability of the coated electrode composites to reduce water nitrate concentrations below regulatory limits. Next, the system was scaled up from the single cell (electrode area $\approx 25 \mathrm{~cm}^{2}$ ) to an eight-cell flow CDI reactor (electrode area $\approx 1814 \mathrm{~cm}^{2}$ ) and the results from this much larger system presented. Finally, multicomponent electrolyte experiments $\left(\mathrm{Na}^{+} \mathrm{Ca}^{2+}, \mathrm{Cl}^{-}\right.$and $\left.\mathrm{NO}_{3}{ }^{-}\right)$were performed to observe if any synergistic, antagonistic or even ion selective processes occur in this process.

\section{Materials and Methods}

\subsection{Materials}

Low surface area carbon fiber (CF) sheet electrodes $\left(2 \mathrm{~m}^{2} \mathrm{~g}^{-1}\right.$ in BET area) employed in this study were previously described elsewhere [30,32]. For these experiments, the CF sheets were either uncoated (for baseline comparisons) or coated with a nano-porous thin film of either $\mathrm{SiO}_{2}$ or $\gamma-\mathrm{Al}_{2} \mathrm{O}_{3}$ as previously described $[30,32]$. Briefly, the coating process consisted of three steps: (1) CF sheets were heated at $350{ }^{\circ} \mathrm{C}$ for 2.5 hours in air; (2) $\mathrm{CF}$ sheets were immersed in $\mathrm{SiO}_{2}$ or $\gamma$-AlOOH sols; (3) $\mathrm{CF}$ sheets coated with oxides were fired at $350{ }^{\circ} \mathrm{C}$ for 2.5 hours to 
sinter the particles to the $\mathrm{CF}$ sheets. The resulting content of metal oxide deposited on the $\mathrm{CF}$ sheets (by wt $\%$ of the entire electrode) was between 3.8-6.7 \% for the $\mathrm{SiO}_{2}$ composites $($ composites $=\mathrm{CF}$ sheet + metal oxide $)$ and 3.2-3.8 $\%$ for the $\gamma-\mathrm{Al}_{2} \mathrm{O}_{3}$ composites. BET surface areas of the $\mathrm{SiO}_{2}$ and $\gamma-\mathrm{Al}_{2} \mathrm{O}_{3}$ composite electrodes were $26-35 \mathrm{~m}^{2} \mathrm{~g}^{-1}$ and $18-19 \mathrm{~m}^{2} \mathrm{~g}^{-1}$ respectively.

\subsection{Methods}

\subsubsection{Small CDI Three Electrode Cell}

Initial experiments were conducted in a batch reactor using a three-electrode

electrochemical cell (Fig 1). Two electrodes $(5.08 \mathrm{~cm} \times 5.08 \mathrm{~cm})$ were separated by 2 pieces of a non-conductive open mesh ( $0.1 \mathrm{~mm}$ thick) and employed as the working and counter electrodes, while a saturated calomel electrode (SCE) was used as the reference electrode. Experiments were performed by placing either two uncoated $\mathrm{CF}$ sheets ('symmetric' configuration), or a $\mathrm{SiO}_{2}$ coated sheet as the working electrode and an $\gamma-\mathrm{Al}_{2} \mathrm{O}_{3}$-coated sheet as the counter electrode ('asymmetric' configuration).

Electrosorption experiments were performed by immersing the electrodes in a vessel filled with $40 \mathrm{ml}$ of electrolyte solution, stirred with a magnetic stir bar. A constant potential of $-1.5 \mathrm{~V}$ was then applied between the WE (cathode during removal) and the reference electrode for 20 min using a potentiostat (Princeton Applied Research, VMP2). In the regeneration phase (desorption of ions from the electrode), the potential was switched to $+0.7 \mathrm{~V}$ for $20 \mathrm{~min}$.

Experiments were repeated three times using different electrode pairs (previously conditioned), with the exception of 6 meq $\mathrm{L}^{-1}$ and the multistep experiments that were repeated twice showing in all cases good repeatability.

Samples were withdrawn from the solution at 5 min intervals and analyzed by ion chromatography (Dionex ICS-2100, Column: Dionex Ion Pac ${ }^{\circledR}$ AS9-HC 4 x 25 mm Analytical). The $\mathrm{pH}$ of the electrolyte was measured before starting the CDI experiment and at the end of the 
removal and regeneration phases. Electrolyte solutions employed in this part of the study, $\mathrm{NaNO}_{3}$, $\mathrm{Ca}\left(\mathrm{NO}_{3}\right)_{2}$ and $\mathrm{CaCl}_{2}$ (Fisher Scientific), were prepared in $18.2 \mathrm{M} \Omega$ high-purity water. For data analysis, ion concentrations are expressed as $\mathrm{mmol} \mathrm{L}^{-1}$ or $\mathrm{mEq} \mathrm{L}^{-1}\left(\mathrm{mEq} \mathrm{L} \mathrm{L}^{-1}=\mathrm{mmol} \mathrm{L}^{-1} \times 2\right.$ for $\mathrm{Ca}^{2+}$ and $\mathrm{mmol} \mathrm{L}^{-1} \times 1$ for $\mathrm{Na}^{+}, \mathrm{NO}_{3}{ }^{-}$and $\left.\mathrm{Cl}^{-}\right)$.

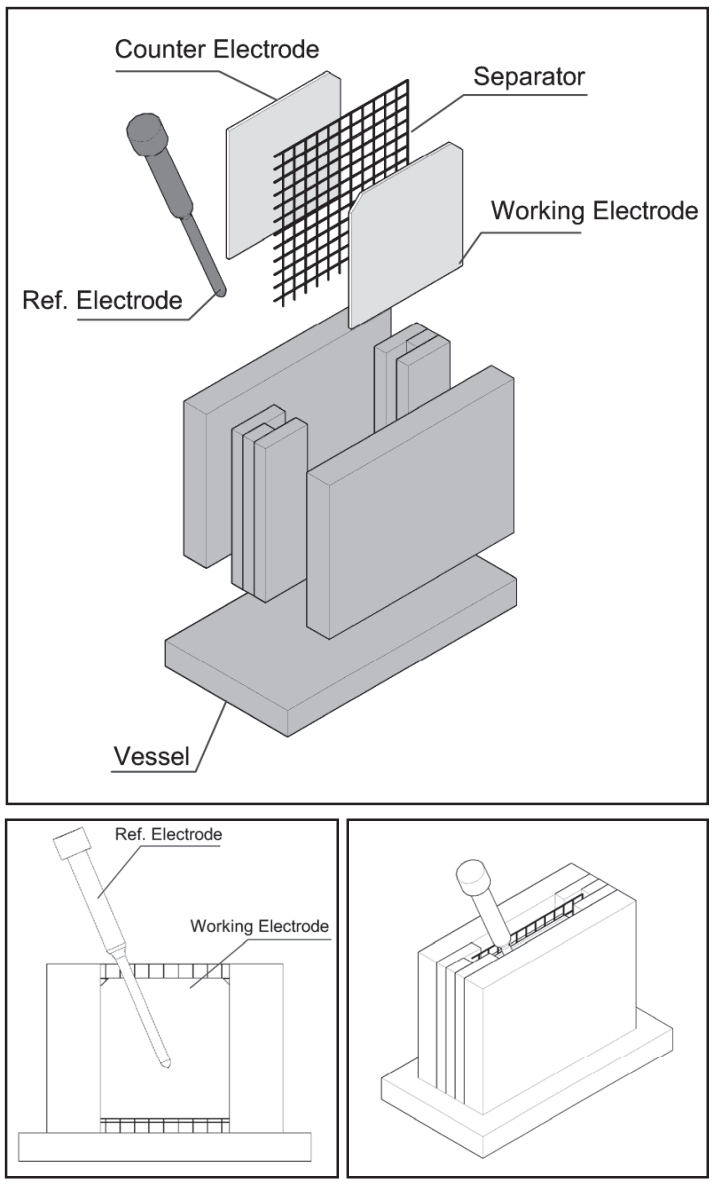

Fig. 1. Schematic of the CDI cell employed in the small-scale CDI experiments.

\subsubsection{Scaling-Up the Process - CDI Flow Reactor}

A scaled-up process (Fig. 2) was conducted by upgrading from the three-electrode electrochemical cell with a fixed cell volume described above ( $40 \mathrm{ml}$ of solution, two electrodes with geometric areas of $\approx 25 \mathrm{~cm}^{2}$ each) to a CDI reactor outfitted with 8 flow cells electrically and hydraulically connected in parallel. The reactor held $\approx 520 \mathrm{ml}$ of water and had sixteen 
electrodes each having an area of $\approx 116.5 \mathrm{~cm}^{2}$. The electric potential was applied between the $\mathrm{SiO}_{2}$ (cathodes, i.e. those negatively charged during the removal step) and $\mathrm{Al}_{2} \mathrm{O}_{3}$ coated (anodes, i.e. those positively charged during the removal step) electrodes instead of applying the voltage between the $\mathrm{SiO}_{2}$ coated electrode (working electrode) and the SCE (reference electrode). CDI experiments described in this section were performed using a CDI system described in detail in previous publications $[25,26]$. Briefly, the CDI reactor was outfitted with 8 cells each of them having two oxide coated carbon electrodes $\left(116.5 \mathrm{~cm}^{2}\right.$ each $)$ separated by a non-conductive Teflon mesh and hydraulically sealed with rubber gaskets. Batch experiments were performed by pumping $720 \mathrm{ml}$ of electrolyte solution from a cylinder $\left(45 \mathrm{ml} \mathrm{min}^{-1}\right.$ constant flow rate) through the CDI system using an Omega FPUDX 1703A metering pump while conductivity and $\mathrm{pH}$ were measured inline by Omega probes (CDE-1201-conductivity and PHE-7357-10-pH) located in the inlet and the outlet of the reactor. A power supply (GW Instek GPD-3303S) was employed to apply the potential difference between the electrodes and the electric currents were measured using an Agilent 34405A multimeter electrically connected in series to the CDI unit. After passing through the system, samples were withdrawn at different times and ion concentrations determined by ion chromatography. It should also be noted that before performing the nitrate experiments described in this paper, the electrodes in the reactor were conditioned by performing 15 batch CDI experiments (removal/regeneration cycles) prior to the nitrates experiments. High purity water was flushed through the CDI system for 30 min after each one of the experiments as part of the cleaning step. 


\section{Proof of Concept Three Electrode Cell}

2 Carbon Electrodes

1 Reference Electrode

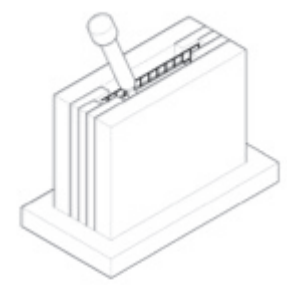

Volume: $40 \mathrm{~mL}$

Electrode Area : $25 \mathrm{~cm}^{2}$

Total Electrode Area: $50 \mathrm{~cm}^{2}$

\section{Proof of Scale-Up \\ CDI Flow Reactor}

16 Carbon Electrodes

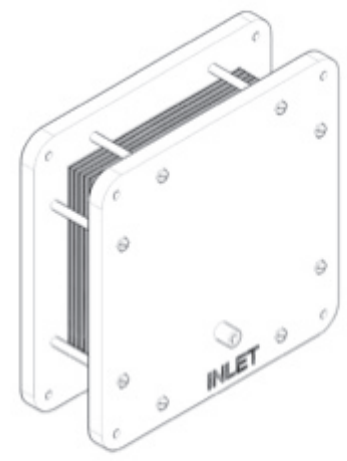

Volume: $520 \mathrm{~mL}$

Electrode Area : $117 \mathrm{~cm}^{2}$

Total Electrode Area: $1864 \mathrm{~cm}^{2}$

Fig. 2. Scaled-up process from a fixed volume three-electrode cell to an eight-cell (each cell composed of two electrodes) CDI flow reactor.

\subsubsection{Electrode Charging Properties - Zeta Potential Measurements}

To investigate the charging properties of the metal oxide composite electrodes when different electrolytes were used in the electrosorption experiments, zeta potential measurements (Malvern Zetasizer 3000HSA) of the powdered $\mathrm{SiO}_{2}$ and $\gamma-\mathrm{Al}_{2} \mathrm{O}_{3}$ xerogels were performed. Powdered $\gamma-\mathrm{Al}_{2} \mathrm{O}_{3}$ xerogel was used as surrogate materials for the composite electrodes. Measurements were taken at different $\mathrm{pH}$ values in electrolyte solutions $\left(\mathrm{NaNO}_{3}, \mathrm{NaCl}\right.$ and $\mathrm{Na}_{2} \mathrm{SO}_{4}$ ) with the same ionic strength $\mathrm{I}=0.01 \mathrm{~mol} \mathrm{~L}^{-1}$.

\section{Results \& Discussion}

\section{1. "Proof of Concept": Small-Scale Experiments}

\subsubsection{Effect of the Metal Oxide Coatings on Nitrate Removal}

CDI experiments were performed in a $1.6 \mathrm{mmol} \mathrm{L}^{-1} \mathrm{NaNO}_{3}$ solution with the coated composite electrodes and the uncoated carbon electrodes to test the effect of the metal oxide 
coatings on $\mathrm{NO}_{3}{ }^{-}$removal. As shown in Fig. 3, when both electrodes were left uncoated, only $12 \%$ of the initial $\mathrm{NO}_{3}{ }^{-}$concentration and $5 \%$ of the $\mathrm{Na}^{+}$was removed during the 20 -min removal period. However, when the coated electrodes were submitted to the same testing, a significant increase in ion removal was observed. After $15 \mathrm{~min}$ of removal, $50 \%$ of the $\mathrm{NO}_{3}{ }^{-}$and $56 \%$ of the $\mathrm{Na}^{+}$was removed.

The above results agree well with previous experiments conducted using $\mathrm{CaCl}_{2}$ solutions and a similar experimental approach $[29,32]$. Those studies showed that the enhancement of the specific surface area and specific capacitance achieved by the coatings had a direct influence on the electrosorption of ions $[29,30]$. However, these previous studies also showed asymmetric ion removal in terms of the charge equivalents of $\mathrm{Ca}^{2+}$ and $\mathrm{Cl}^{-}$removed; specifically, more $\mathrm{mEq} \mathrm{L}^{-1}$ of $\mathrm{Ca}^{2+}$ were removed than $\mathrm{Cl}^{-}$. This removal was accompanied by a large $\mathrm{pH}$ drop or increase in $\mathrm{H}^{+}$concentration (one of the main species responsible for maintaining the requirement of electrical neutrality in solution). In addition, the authors also observed faradaic reactions such as the oxidation of chloride to chlorate at the same applied potential $(-1.5 \mathrm{~V}$ vs. SCE) $[29,32]$. In contrast to these previous CDI studies, the $\mathrm{pH}$ values measured in this study using $\mathrm{NaNO}_{3}$ did not reveal a large $\mathrm{pH}$ drop $(\mathrm{pH}$ before removal step $(\approx 5.3)$ and after $(\approx 5.0))$ or asymmetric ion removal.

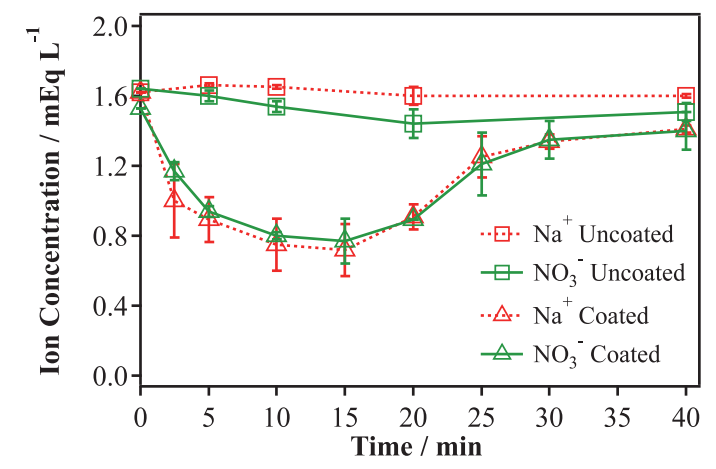

Fig. 3. Removal (0 to $20 \mathrm{~min}$ ) and regeneration (20 to $40 \mathrm{~min}$ ) of a CDI cell composed of two uncoated carbon electrodes in comparison with a CDI cell outfitted with a $\mathrm{SiO}_{2}$ coated carbon as the negative electrode and $\gamma-\mathrm{Al}_{2} \mathrm{O}_{3}$ coated carbon as the positive during removal. 


\subsubsection{Influence of the Cation on Nitrate Removal}

In order to investigate whether the cation species in solution influence the adsorption of nitrates on the opposite electrode, experiments were performed with a $1.6 \mathrm{mmol} \mathrm{L}{ }^{-1} \mathrm{Ca}\left(\mathrm{NO}_{3}\right)_{2}$ solution and compared with the results obtained using a $\mathrm{NaNO}_{3}$ solution. The ion concentration profile over time (Fig. 4A) showed very similar nitrate removal trends using these different salts; the maximum amount of nitrate removed was $0.017 \pm 0.03$ and $0.015 \pm 0.03 \mathrm{mEq} \mathrm{g}^{-1}$ for $\mathrm{NaNO}_{3}$ and $\mathrm{Ca}\left(\mathrm{NO}_{3}\right)_{2}$ respectively. However, the removal kinetics of $\mathrm{Ca}^{2+}$ and $\mathrm{Na}^{+}$(Fig. 4B) appeared quite different. Sodium adsorption was fast at the beginning of the experiment and leveled off after approximately 10 minutes. In addition, the shape of the $\mathrm{Na}^{+}$kinetic curve appeared similar to that observed for nitrate removal. On the other hand, the $\mathrm{Ca}^{2+}$ ions were slowly adsorbed at the beginning of the test (first $5 \mathrm{~min}$ ), but then were continually removed in a nearly linear fashion for the remainder of the experiment.
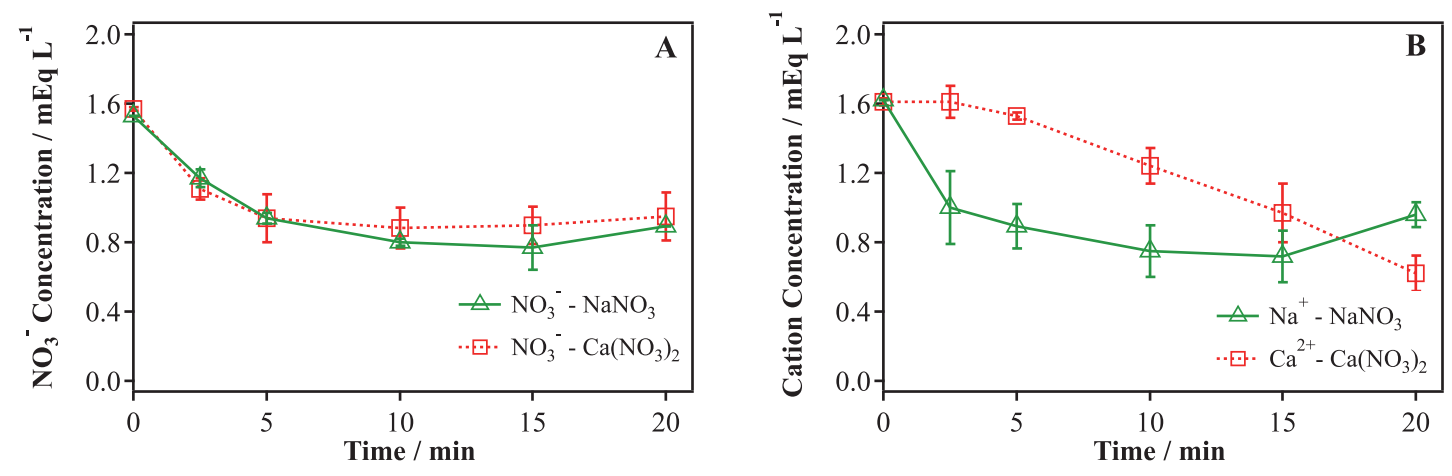

Fig. 4. Time profiles of nitrate (A) and cation (B) concentrations during electrosorption experiments when either $\mathrm{Ca}\left(\mathrm{NO}_{3}\right)_{2}$ or $\mathrm{NaNO}_{3}$ were employed as electrolytes in the $\mathrm{CDI}$ experiments.

Different hypothesis could be used to explain this behavior. First, it appears that monovalent ions with smaller hydrated radius $\left(\mathrm{Na}^{+}: 358 \mathrm{pm}, \mathrm{NO}_{3}^{-}: 335 \mathrm{pm}\right)[39]$ were adsorbed faster than $\mathrm{Ca}^{2+}$ whose hydrated radius is larger (412 pm) [39]. Thus, a higher monovalent ion 
adsorption was observed at the beginning of the experiment while divalent ions were preferentially adsorbed at longer times of operation. Zhao et al. [40] also reported slower removal kinetics for the divalent ion $\left(\mathrm{Ca}^{2+}\right)$ than that of the monovalent $\left(\mathrm{Na}^{+}\right)$in $\mathrm{CDI}$ experiments using multicomponent electrolytes. These authors suggested a time dependence on ion selectivity in the electrical double layer (EDL) based on transport resistance of ions outside the EDL and the ion adsorption capacity of the EDL which in turn depends on the applied voltage during the experiment.

A second hypothesis that could explain this behavior might be related to the different ion removal mechanism for $\mathrm{NO}_{3}{ }^{-}, \mathrm{Ca}^{2+}$ and $\mathrm{Na}^{+}$. This hypothesis is based on previous work where the electrophoretic mobility of $\mathrm{SiO}_{2}$ particles suspended in $\mathrm{NaCl}$ and $\mathrm{CaCl}_{2}$ solutions at different $\mathrm{pH}$ values was studied [32]. In this work, $\mathrm{Ca}^{2+}$ ions were found to show a certain affinity for $\mathrm{SiO}_{2}$ particles, seemingly indicative of specific adsorption noted by a shift in the isoelectric $\mathrm{pH}\left(\mathrm{pH}_{\mathrm{iep}}\right)$. On the other hand, this behavior was not observed in the presence of sodium ions. These observations suggest that two different processes may remove $\mathrm{Ca}^{2+}$ ions: electroadsorption in the EDL and specific adsorption on the $\mathrm{SiO}_{2}$ coating. In contrast, these findings also imply that $\mathrm{Na}^{+}$ ions are only removed by electroadsorption in the EDL. In this manuscript, the zeta potential of $\mathrm{Al}_{2} \mathrm{O}_{3}$ particles suspended in $\mathrm{NaCl}, \mathrm{NaNO}_{3}$ and $\mathrm{Na}_{2} \mathrm{SO}_{4}$ was measured to detect shifts in the $\mathrm{pH}_{\text {iep, }}$, indicative of specific adsorption of $\mathrm{NO}_{3}{ }^{-}$ions. The results, displayed in Fig. 5, show that the $\mathrm{pH}_{\text {iep }}$ of the $\mathrm{Al}_{2} \mathrm{O}_{3}$ particles is around 9 for $\mathrm{NaCl}$ and $\mathrm{NaNO}_{3}$, meaning these particles will have positive surface charges at $\mathrm{pH}$ values below $\sim 9$. However, the figure also shows that sulfate ions reduce the $\mathrm{pH}_{\text {iep }}$ of the $\mathrm{Al}_{2} \mathrm{O}_{3}$, which is indicative of specific adsorption of sulfate on the $\mathrm{Al}_{2} \mathrm{O}_{3}$ particles. The differences in behavior between chloride and nitrate from that of sulfates reveals that one would not expect to observe any specific adsorption of the $\mathrm{Cl}^{-}$or the $\mathrm{NO}_{3}{ }^{-}$ions on the $\mathrm{Al}_{2} \mathrm{O}_{3}$ particles. This implies that the only ion removal mechanism for $\mathrm{Na}^{+}$and $\mathrm{NO}_{3}{ }^{-}$seems to be that of electro-adsorption in the EDL. Based on this analysis, one might suggest that the lack of specific adsorption of monovalent ions on the metal oxide could influence the kinetics of this 
electroadsorption process (i.e. - specific adsorption should not play a role in the removal kinetics of monovalent ions such as $\mathrm{NO}_{3}{ }^{-}$and $\mathrm{Cl}^{-}$in the $\mathrm{CDI}$ process, but may with anions such as $\mathrm{SO}_{4}{ }^{2-}$ ).

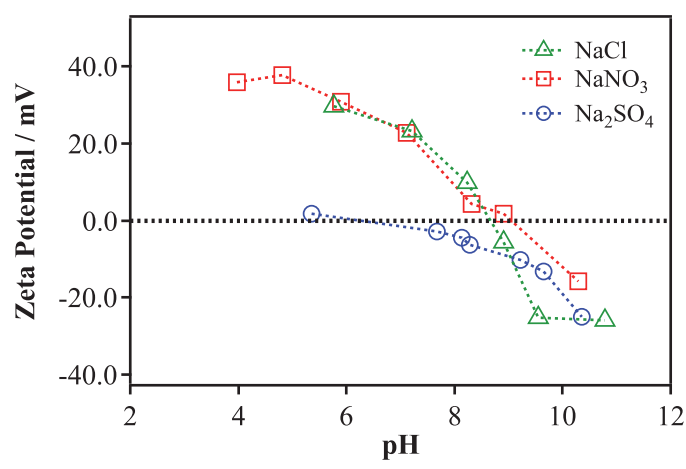

Fig. 5. Electrophoretic mobility curves for $\gamma-\mathrm{Al}_{2} \mathrm{O}_{3}$ particles in different electrolytes $(\mathrm{NaCl}$, $\mathrm{Na}_{2} \mathrm{SO}_{4}$ and $\left.\mathrm{NaNO}_{3}\right)$.

\subsubsection{Influence of Nitrate Concentrations and a Comparison to other Anions - Asymmetric Removal}

An additional consequence of the different ion adsorption profiles observed for $\mathrm{Ca}^{2+}$ and $\mathrm{NO}_{3}{ }^{-}$ions (Fig. 4) was the asymmetric ion removal with respect to charge. The experiment performed using $\mathrm{Ca}\left(\mathrm{NO}_{3}\right)_{2}$ showed the occurrence of asymmetric removal during the entire duration of the experiment (after $20 \mathrm{~min}, \mathrm{Ca}^{2+}: 0.020 \mathrm{mEq} \mathrm{g}^{-1}>\mathrm{NO}_{3}{ }^{-}: 0.014 \mathrm{mEq} \mathrm{g}^{-1}$ ), in contrast to the experiment performed with $\mathrm{NaNO}_{3}\left(\mathrm{Na}^{+}: 0.013 \mathrm{mEq} \mathrm{g}^{-1} \approx \mathrm{NO}_{3}^{-}: 0.015 \mathrm{mEq} \mathrm{g}^{-1}\right)$. Moreover, $\mathrm{pH}$ measurements taken at the beginning and at the end of the removal phase showed that while the $\mathrm{pH}$ had a slight decrease in the case of the experiments performed with $\mathrm{NaNO}_{3}$ (from 5.4 to 5.1), a significant $\mathrm{pH}$ decay (from 5.8 to 3.8) was observed when $\mathrm{Ca}\left(\mathrm{NO}_{3}\right)_{2}$ was used as the electrolyte. Since the same potential was applied irrespective of the cations tested, the $\mathrm{pH}$ drop appeared, in this case, to be associated with asymmetric removal rather than the occurrence of faradaic reactions such as water electrolysis, carbon oxidation and oxygen or proton reduction reactions $[25,41,42]$. 
In order to study the effect of the initial electrolyte concentration on asymmetric removal, a further experiment using $\mathrm{Ca}\left(\mathrm{NO}_{3}\right)_{2}$ at a higher concentration $\left(6 \mathrm{mEq} \cdot \mathrm{L}^{-1}\right)$ was performed. Results of this experiment, displayed in Fig. 6A, clearly indicate that asymmetric removal (with respect to charge of the ionic species $\mathrm{Ca}^{2+}$ vs. $\mathrm{NO}_{3}{ }^{-}$) is occurring; particularly, when the electrolyte concentration is increased. Thus, $\mathrm{Ca}^{2+}$ removal obtained after 20 min was much higher $\left(0.079 \mathrm{mEq} \mathrm{g}^{-1}\right)$ than the $\mathrm{NO}_{3}$ removal $\left(0.041 \mathrm{mEq} \mathrm{g}^{-1}\right)$. For comparison purposes, a supplementary experiment was performed using a different anion $\left(\mathrm{CaCl}_{2}, 6 \mathrm{mEq} \mathrm{L}^{-1}\right)$. Results displayed in (Fig. 6B) confirmed the asymmetric ion removal characterized by a higher adsorption of $\mathrm{Ca}^{2+}$ than $\mathrm{Cl}^{-}$. In addition to this similarity, electrosorption experiments conducted with $\mathrm{Ca}\left(\mathrm{NO}_{3}\right)_{2}$ and $\mathrm{CaCl}_{2}$ were in both cases accompanied by a decrease in $\mathrm{pH}$ values (from 5.2 to 2.9). The findings regarding $\mathrm{CaCl}_{2}$ were explained in previous studies $[29,32]$ and likely based on the occurrence of chloride oxidation to chlorates, the specific adsorption of the $\mathrm{Ca}^{2+}$ ions onto the oxide phase $\left(\mathrm{SiO}_{2}\right)$ of the composite electrode and the oxidation of the carbon electrode. Conversely, while $\mathrm{Ca}^{2+}$ sorption appears driven by EDL electro-sorption and specific adsorption in both the $\mathrm{CaCl}_{2}$ and $\mathrm{Ca}\left(\mathrm{NO}_{3}\right)_{2}$ systems, no evidence of parasitic reactions involving $\mathrm{NO}_{3}{ }^{-}$ions, determined by the absence of any new nitrogen compounds in the ion chromatographs, were observed in the experiments discussed in this study. Therefore, it appears that the higher removal of $\mathrm{Ca}^{2+}$ over $\mathrm{NO}_{3}{ }^{-}$ions seems to be a major contributor to the $\mathrm{pH}$ decrease along with other faradaic reactions such as carbon oxidation, and oxygen reduction that might occur during the experiment.
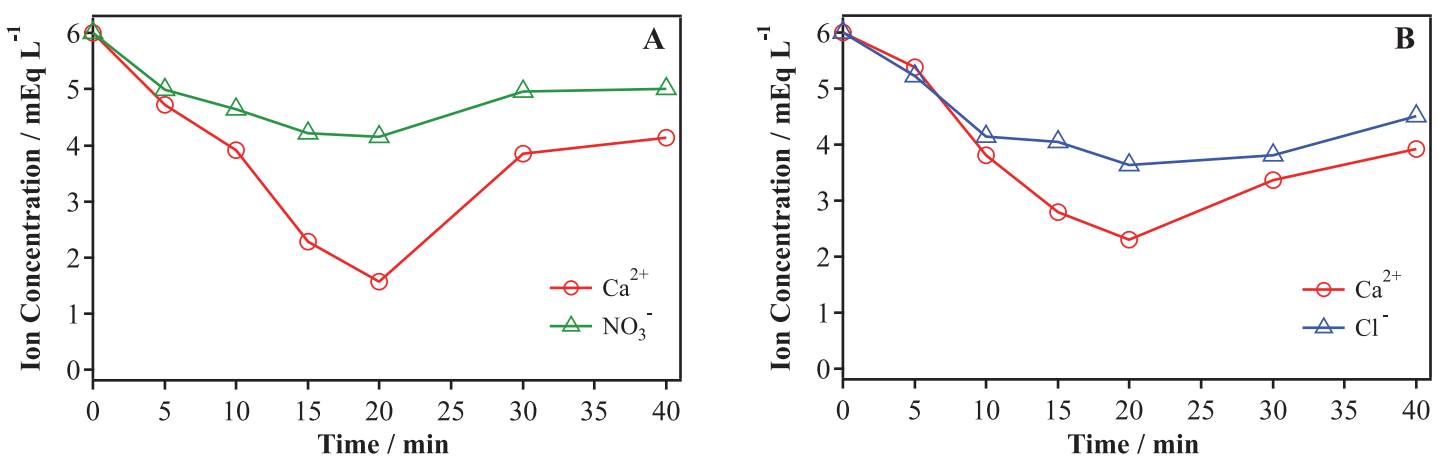
Fig. 6. Electrosorption experiments performed using $\mathrm{Ca}\left(\mathrm{NO}_{3}\right)_{2}(\mathrm{~A})$ and $\mathrm{CaCl}_{2}$ (B) electrolyte.

\subsubsection{Single Step vs Multistep Nitrate Removal with Capacitive Deionization}

With the goal of reducing nitrate concentrations from $100 \mathrm{mg} \mathrm{L}^{-1}\left(1.6 \mathrm{mEq} \mathrm{L}^{-1}\right.$ of $\left.\mathrm{NO}_{3}{ }^{-}\right)$ to values below the WHO-advised level of $45 \mathrm{mg} \mathrm{L}^{-1}$ as $\mathrm{NO}_{3}^{-}\left(0.7 \mathrm{mEq} \mathrm{L}^{-1}\right.$ of $\left.\mathrm{NO}_{3}^{-}\right)$, an alternative method of operation was explored. Based on the results displayed in Fig. 4, where the nitrate removal appeared to level off after approximately 10 min of operation, a multistep operational mode was studied. In the multistep mode after 10 minutes of removal, the electrode pair was manually lifted from the "feed" solution $\left(100 \mathrm{mg} \mathrm{L}^{-1} \mathrm{NO}_{3}^{-} ; 1.6 \mathrm{mEq} \mathrm{L}^{-1} \mathrm{NaNO}_{3}\right.$,) and brought into contact with another solution (namely "brine") contained in another vessel. Initially, the brine solution had half the salt concentration of the feed solution. After 5 min of regenerating the electrode pair by (applying $+0.7 \mathrm{~V}$ vs. SCE), the pair was moved back into the initial solution. A new removal period using the same conditions as in the first removal step was conducted for 5 more minutes. This process was repeated two more times for a total of three $5 \mathrm{~min}$ immersions for the removal phase, i.e. -25 minutes of total removal time $(10+5+5+5$ minutes $)$. A similar operational method previously described as "electrodes in motion" was successfully tested using carbon coated wires as CDI electrodes [16]. The idea behind this operational mode was to simulate the CDI process under more realistic (real-world) operational parameters, where the treated solution and the brine solution are replaced depending on whether the CDI system is in the removal or regeneration phase.

Fig. 7 shows the nitrate concentration profiles of single and multiple cycle experiments. This graph illustrates the increase in nitrate removal from 50 to $61 \%$ upon multiple immersions. In this way, a nitrate concentration of $39 \mathrm{mg} \mathrm{L}^{-1}\left(0.6 \mathrm{mEq} \mathrm{L}^{-1}\right.$ of $\left.\mathrm{NO}_{3}^{-}\right)$, which is below the health advisory limit ( $\left.45 \mathrm{mg} \mathrm{L}^{-1}\right)$, was achieved. Fig. 7 also shows that by extending the number of cycles $(n=4)$ the nitrate concentration could be reduced down to $32 \mathrm{mg} \mathrm{L}^{1}\left(0.5 \mathrm{mEq} \mathrm{L}^{-1}\right.$ of $\left.\mathrm{NO}_{3}{ }^{-}\right)$ translating into $68 \%$ nitrate removal. A further analysis of the nitrate removal rate per cycle 
indicates that the first cycle showed faster ion removal $\left(4.20 \mathrm{mg} \mathrm{L}^{-1} \mathrm{~min}^{-1}\right)$ than consecutive cycles, where the removal rate substantially decreased $\left(1.37,2.33\right.$ and $\left.1.50 \mathrm{mg} \mathrm{L}^{-1} \mathrm{~min}^{-1}\right)$. A plausible reason for this finding could be related to incomplete salt desorption during the electrode regeneration phase thus leading to a reduction in the nitrate removal rate in subsequent removal cycles. Moreover, the reduction of ion conductivity in the solution at lower nitrate concentrations might also lead to slower removal rates due to the increase in ionic resistance of the solution. The mass balance calculation using nitrate data support this hypothesis indicating that the amount of nitrate adsorbed during removal was not fully desorbed during the regeneration phase (data not shown). Based on this, the progressive electrode saturation suffered cycle by cycle led to the ion electrosorption capacity reduction. The authors suggest that longer electrode regeneration periods might help solve this issue. Despite this, when examining Fig. 7, an increase in nitrate concentration in the brine solution with successive cycling is observed. This result seems to indicate the ability to concentrate a brine solution, and this could have an important impact on reducing the cost of brine disposal. Lastly, it should be noted that $\mathrm{pH}$ measurements taken at the end of each removal step $\left(\mathrm{pH}_{0}=6.7 ; \mathrm{pH}_{10}=5.97 ; \mathrm{pH}_{15}=5.90 ; \mathrm{pH}_{20}=5.99 ; \mathrm{pH}_{25}=\right.$ 5.92) supports the results obtained in previous experiments performed with $\mathrm{NaNO}_{3}$ electrolyte where no significant $\mathrm{pH}$ changes were observed.

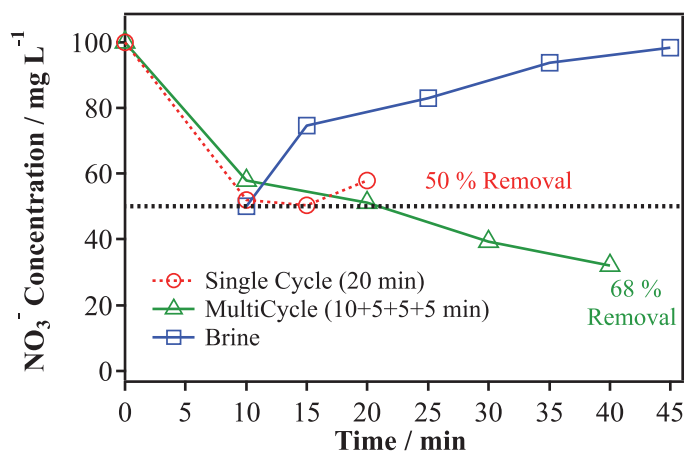

Fig. 7. Different operational modes for nitrate removal using a three-electrode CDI cell.

\subsubsection{Flow Cell Reactor Performance: Influence of Applied Voltage on Nitrate Removal}


The above sections display the "proof of concept" that the metal oxide coated electrodes can successfully decrease nitrate concentration below regulatory limits and that coatings greatly improve the ion removal capabilities of the electrode. However, the above tests were performed in a small bench scale reactor, treating only $40 \mathrm{ml}$ of solution. In this section, we examine the ability of a flow cell CDI reactor that has over $37 \mathrm{x}$ the electrode area $\left(50 \mathrm{~cm}^{2} \mathrm{vs} .1864 \mathrm{~cm}^{2}\right)$ of the small scale reactor and will treat $18 \mathrm{x}$ the volume of water $(40 \mathrm{ml} v \mathrm{vs} .720 \mathrm{ml})$. With this in mind, a group of batch experiments in which the applied cell voltage between the electrodes was increased from 1.0 to $1.5 \mathrm{~V}$ for $150 \mathrm{~min}$ and flow rate was kept at $45 \mathrm{ml} \mathrm{min}^{-1}$ were performed by recirculating $\approx 720 \mathrm{ml}$ of a $1.9 \mathrm{mEq} \mathrm{L} \mathrm{L}^{-1} \mathrm{Ca}\left(\mathrm{NO}_{3}\right)_{2}\left(120 \mathrm{mg} \cdot \mathrm{L}^{-1}\right.$ as $\left.\mathrm{NO}_{3}\right)$ electrolyte solution throughout the reactor. Fig. 8 shows that the application of a higher cell voltage resulted in increasing nitrate removal from $44 \%(1.0 \mathrm{~V})$ to $56 \%(1.5 \mathrm{~V})$. Hence, the initial nitrate concentration, $\approx 120 \mathrm{mg} \mathrm{L}^{-1,}\left(1.9 \mathrm{mEq} \mathrm{L}^{-1} \mathrm{NO}_{3}{ }^{-}\right)$was reduced to a value of $\approx 54 \mathrm{mg} \mathrm{L}^{-1}(0.9 \mathrm{mEq}$ $\mathrm{L}^{-1} \mathrm{NO}_{3}{ }^{-}$) when the highest voltage was applied. This value is fairly close to the limit specified in the aforementioned regulation $\left(45 \mathrm{mg} \mathrm{L}^{-1}\right.$ as $\left.\mathrm{NO}_{3}{ }^{-}\right)$.

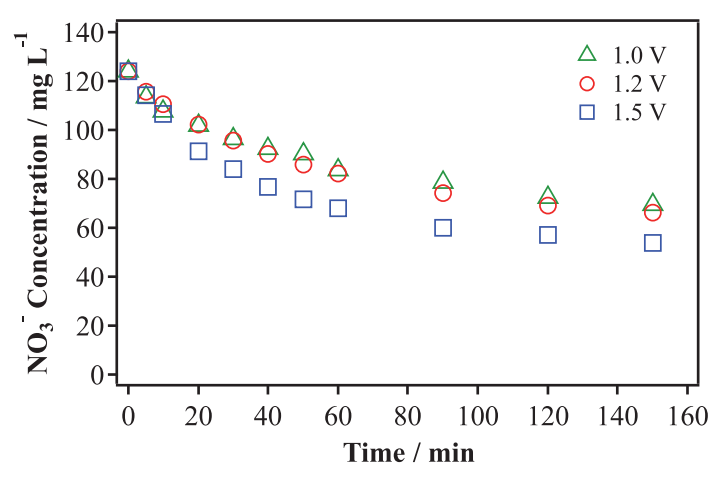

Fig. 8. Effect of Cell Voltage on Nitrate Removal

As was the case for the small cell, the occurrence of asymmetric removal was also studied in the experiments performed with the flow reactor. However, in the case of the flow reactor experiments, the effect of the cell voltage was evaluated for a longer period of time (240 min). Fig. 9 shows the influence of the cell voltage on the ion concentration versus time profiles 
along with the changes in $\mathrm{pH}$. Results displayed in Fig. 9A-C once again demonstrate that $\mathrm{NO}_{3}{ }^{-}$ removal seemed faster than $\mathrm{Ca}^{2+}$ adsorption for the initial 90 min of all the experiments, regardless of cell voltage. Nevertheless, results also showed that while the nitrate removal kinetics appeared to slow down and level off after 180 min of the experiment, $\mathrm{Ca}^{2+}$ electrosorption continued beyond that point. After applying $1.0 \mathrm{~V}$ for 4 hours (Fig 9A) calcium and nitrate removal equilibrated to fairly symmetric values $\left(\mathrm{NO}_{3}{ }^{-}: 48 \% ; \mathrm{Ca}^{2+}: 47 \%\right.$, in $\left.\mathrm{mEq} \mathrm{L}^{-1}\right)$. However, when the cell voltage was increased from 1.0 to $1.2 \mathrm{~V}$ the above equilibrium was reached just after 90 min and even faster when the applied cell voltage was $1.5 \mathrm{~V}$. In addition, removal of calcium was higher than for nitrate ions with increased potential; after 4 hours, the results showed the following removal ratios at $1.2 \mathrm{~V}: \mathrm{NO}_{3}{ }^{-}: 50 \% ; \mathrm{Ca}^{2+}: 61 \%$ in $\mathrm{mEq} \mathrm{L}^{-1}$, whereas for $1.5 \mathrm{~V}$ these values were $\mathrm{NO}_{3}{ }^{-}: 56 \% ; \mathrm{Ca}^{2+}: 66 \%$ in $\mathrm{mEq} \mathrm{L}^{-1}$.

The first conclusion that might be extracted from these experiments is that higher voltages not only speed up ion removal kinetics of both ions but also reduce the time where the calcium adsorption started to be greater than nitrate removal (Fig 9B and 9C). This result confirms that time dependence of ion removal could be tuned by using cell voltage. Moreover, the results indicate that the occurrence of a time dependent ion removal not only appears when the electrolyte contains cations with different charges (such as $\mathrm{Na}^{+}$and $\mathrm{Ca}^{2+}$ ) [40], but also when the electrolyte contains differently charged anions and cations.

The analysis of the $\mathrm{pH}$ curves leads one to conclude that for all of the selected cell voltages, ion removal was followed by a decrease in $\mathrm{pH}$. Thus, $\mathrm{pH}$ decreased from values between $6.9-7.5$, to $4.9(1.0 \mathrm{~V}), 4.7(1.2 \mathrm{~V})$ and $4.5(1.2 \mathrm{~V})$ after $240 \mathrm{~min}$. This $\mathrm{pH}$ decrease, in the same way as ion removal, seemed to be time dependent, showing that longer times of operation, in all cases, lead to lower values of $\mathrm{pH}$. In the previous section, the observed $\mathrm{pH}$ drop was associated with the compensation of the solution ion balance displaced by the higher removal of $\mathrm{Ca}^{2+}$ over $\mathrm{NO}_{3}{ }^{-}$ions. The pH-time profiles displayed in Fig. 9A-C supports this hypothesis since the application of higher cell voltages speeds up calcium removal over that of nitrate leading to 
more drastic decreases in $\mathrm{pH}$. In addition, carbon oxidation reactions might be also occurring at high voltages contributing to the solution acidification as well. The occurrence of this kind of faradaic reactions could be justified by the increase of the current density values observed in the transient part of the curves when the applied cell voltage was boosted (Fig. 9D). Choi studies about the CDI performance at constant current [42] determined that while $\mathrm{pH}$ effluent decreases slowly at the beginning of the experiment at low current densities, deeper $\mathrm{pH}$ changes were observed when the CDI experiments were performed at higher current densities.
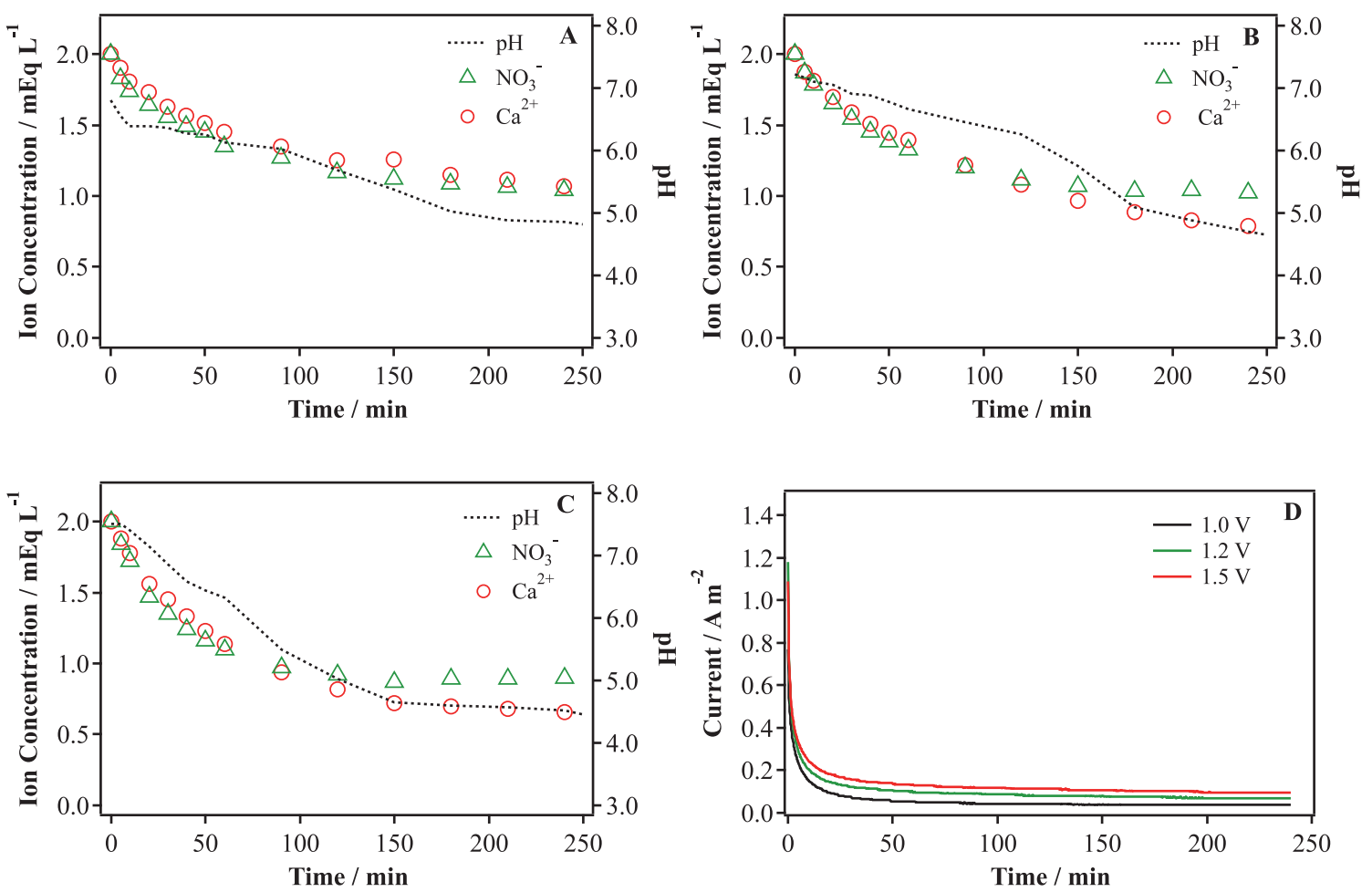

Fig. 9. Effect of cell voltage on the symmetry of ion removal: $1.0 \mathrm{~V}(\mathrm{~A}), 1.2 \mathrm{~V}(\mathrm{~B}), 1.5 \mathrm{~V}(\mathrm{C})$ and current density (D).

\subsubsection{Multicomponent Electrolyte Experiments}

To investigate the electrosorption of nitrate in an experiment more closely tied to real world scenarios, additional experiments were performed with the CDI reactor using a 
multicomponent electrolyte. A CDI batch experiment was conducted using a $2 \mathrm{mEq} \mathrm{L}^{-1} \mathrm{Na}^{+}, \mathrm{Ca}^{2+}$, $\mathrm{Cl}^{-}, \mathrm{NO}_{3}{ }^{-}$solution and applying $1.5 \mathrm{~V}$ as a cell voltage. Results reported in Fig. 10 appear to support the hypotheses suggested by single salt experiments. Nitrate removal was initially faster than calcium, but after 60 minutes nitrate removal leveled off while calcium removal continued. After 180 min, $\mathrm{Ca}^{2+}$ removal (33\%) was higher than $\mathrm{NO}_{3}{ }^{-}$removal $(26 \%)$.

Calcium and sodium time profiles were consistent with observations of time-dependent cation selectivity reported by Zhao et al. [40] in CDI experiments with chloride salts. In this work, those findings were also found to be true in an electrolyte solution with two anions. Hence, the difference in removal kinetics between $\mathrm{Ca}^{2+}$ and $\mathrm{Na}^{+}$should be taken into account when developing/operating a CDI water softening system. In terms of anion selectivity, these results showed that nitrate and chloride removal were quite similar albeit that the nitrate electrosorption was slightly slower than that of chloride.

As a final consideration, $\mathrm{pH}$ measurements revealed an acidification of the solution from 7.8 to 5.4. At the beginning of this experiment, a minor drop of $\mathrm{pH}$ from 7.8 to 7.0 was observed. However, the major decay occurred after 60 min coincident with the point where the concentration of the monovalent ions leveled off while the calcium removal continued. Fig. 10 shows that $\mathrm{pH}$ values then decreased from $7.0(60 \mathrm{~min})$ to $5.4(180 \mathrm{~min})$. This result indicates that a decrease in $\mathrm{pH}$ values would be expected when longer times of operation are employed, as long as calcium removal continues. Hence, evaluating the impact of $\mathrm{pH}$ changes on electrode performance in the presence of other ions such as carbonates that might buffer the solution, is an important factor that should be considered when testing the use of CDI as a water softening or nitrate removal system in real world scenarios. 


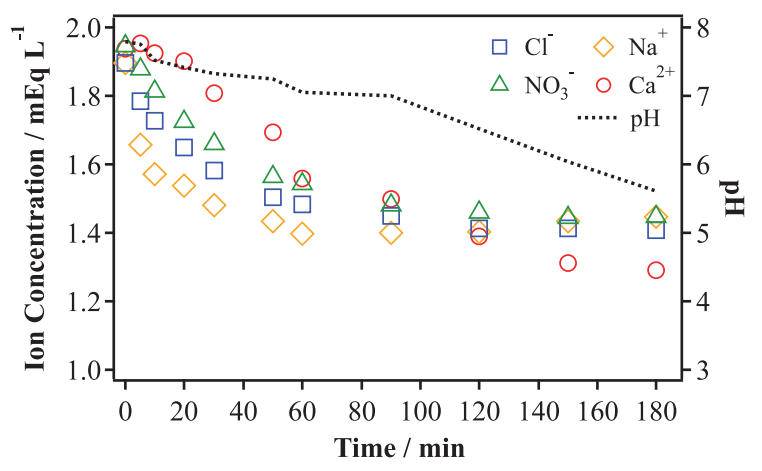

Fig. 10. Ion removal in a multi-component salt experiment.

\section{Conclusions}

In this work, carbon electrodes coated with $\mathrm{SiO}_{2}$ or $\mathrm{Al}_{2} \mathrm{O}_{3}$ showed a higher nitrate removal capacity than uncoated symmetric carbon electrodes. The improvement was likely associated with the metal oxides ability to provide faster ion transport through the carbon electrode due to a reduction in hydrophobicity, an increase in specific surface area and an increase in the number of adsorption sites. It was also determined, by performing CDI experiments using nitrate coupled with either $\mathrm{Na}^{+}$or $\mathrm{Ca}^{2+}$, that while nitrate removal values were similar in both cases, sodium and calcium followed different electrosorption patterns. Particularly, sodium removal followed the nitrate electrosorption pattern while calcium removal was much slower at the beginning of the experiments. Time dependent ion selectivity in the EDL was noted as a plausible explanation for this finding. Moreover, the affinity of $\mathrm{Ca}^{2+}$ ions for $\mathrm{SiO}_{2}$ particles indicates that besides electrosorption in the double layer, specific adsorption of calcium on the silica-coated electrode likely occurs. An important consequence of the time dependency removal was the asymmetric removal observed in the case of $\mathrm{Ca}\left(\mathrm{NO}_{3}\right)_{2}$ experiments and the subsequent $\mathrm{pH}$ acidification of the solution. 
In addition to two step cycling (removal and regeneration) experiments, multi-step experiments showed the potential for the composite electrodes tested to reduce nitrate concentrations below the limits stipulated by the WHO. Furthermore, the regeneration of the electrodes using this mode of operation produced more concentrated waste brines that may have a positive impact on the reduction of brine wastes and process costs.

Finally, an eight-cell flow CDI reactor capable of treating a larger volume of water was successfully tested. Different cell voltage tests with the CDI reactor showed that the time dependence of ion removal could be tuned using applied potentials. Moreover, multicomponent experiments showed the occurrence of time dependent ion removal does not only appear when the electrolyte contains cations with different charges $\left(\mathrm{Ca}^{2+} \mathrm{Na}^{+}\right.$and only $\mathrm{Cl}^{-}$as anion) but also when the electrolyte contains different anions $\left(\mathrm{Cl}^{-}\right.$and $\left.\mathrm{NO}_{3}{ }^{-}\right)$. This conclusion may lead to the possibility of selectively removing certain ions.

\section{Acknowledgements}

Funding for this project was provided by the Spanish Ministry of Industry (TAPCAP Project: ECC-590000-2008-130) and the Office of Naval Research (ONR). The authors also acknowledge use of instrumentation supported by the UW MRSEC (DMR-1121288) and UW NSEC (DMR0832760). Moreover, J. J. Lado acknowledges Comunidad de Madrid for the postdoctoral fellowship as part of the Young Talent Attraction Program (2016-T2/AMB-1310). The authors also thank Chris Worley (UW-Madison) for his technical support.

\section{References}

[1] J. Margat, J. Van der Gun, Groundwater around the world: a geographic synopsis, CRC Press, 2013.

[2] J. Vrba, J. van der Gun, The world's groundwater resources, International Groundwater Resources Assessment Centre, Utrecht, (2004).

[3] W. Tang, P. Kovalsky, D. He, T.D. Waite, Fluoride and nitrate removal from brackish groundwaters by batch-mode capacitive deionization, Water research, 84 (2015) 342-349. 
[4] R. Parette, F.S. Cannon, The removal of perchlorate from groundwater by activated carbon tailored with cationic surfactants, Water Research, 39 (2005) 4020-4028.

[5] A. Bhatnagar, M. Sillanpää, A review of emerging adsorbents for nitrate removal from water, Chemical Engineering Journal, 168 (2011) 493-504.

[6] Z. Zhang, A. Chen, Simultaneous removal of nitrate and hardness ions from groundwater using electrodeionization, Separation and Purification Technology, 164 (2016) 107-113.

[7] K. Wick, C. Heumesser, E. Schmid, Groundwater nitrate contamination: factors and indicators, Journal of environmental management, 111 (2012) 178-186.

[8] H.-F. Chiu, S.-S. Tsai, C.-Y. Yang, Nitrate in drinking water and risk of death from bladder cancer: an ecological case-control study in Taiwan, Journal of Toxicology and Environmental Health, Part A, 70 (2007) 1000-1004.

[9] C.-Y. Yang, S.-S. Tsai, H.-F. Chiu, Nitrate in drinking water and risk of death from pancreatic cancer in Taiwan, Journal of Toxicology and Environmental Health, Part A, 72 (2009) 397-401.

[10] W.H. Organization, Nitrate and nitrite in drinking-water: Background document for development of WHO Guidelines for Drinking-water Quality, (2003).

[11] E. Lacasa, P. Cañizares, C. Sáez, F.J. Fernández, M.A. Rodrigo, Removal of nitrates from groundwater by electrocoagulation, Chemical Engineering Journal, 171 (2011) 1012-1017.

[12] R. Epsztein, O. Nir, O. Lahav, M. Green, Selective nitrate removal from groundwater using a hybrid nanofiltration-reverse osmosis filtration scheme, Chemical Engineering Journal, 279 (2015) 372-378.

[13] J. Ortiz, E. Expósito, F. Gallud, V. García-García, V. Montiel, A. Aldaz, Desalination of underground brackish waters using an electrodialysis system powered directly by photovoltaic energy, Solar Energy Materials and Solar Cells, 92 (2008) 1677-1688.

[14] Y.J. Kim, J.H. Choi, Selective removal of nitrate ion using a novel composite carbon electrode in capacitive deionization, Water Res., 46 (2012) 6033-6039.

[15] Y. Oren, Capacitive delonization (CDI) for desalination and water treatment - past, present and future (a review), Desalination, 228 (2008) 10-29.

[16] M.A. Anderson, A.L. Cudero, J. Palma, Capacitive deionization as an electrochemical means of saving energy and delivering clean water. Comparison to present desalination practices: Will it compete?, Electrochimica Acta, 55 (2010) 3845-3856.

[17] M.E. Suss, S. Porada, X. Sun, P.M. Biesheuvel, J. Yoon, V. Presser, Water desalination via capacitive deionization: what is it and what can we expect from it?, Energy \& Environmental Science, (2015).

[18] P. Dlugolecki, A. van der Wal, Energy Recovery in Membrane Capacitive Deionization, Environmental Science \& Technology, 47 (2013) 4904-4910.

[19] E. Garcia-Quismondo, R. Gomez, F. Vaquero, A.L. Cudero, J. Palma, M. Anderson, New testing procedures of a capacitive deionization reactor, Physical Chemistry Chemical Physics, 15 (2013) 7648-7656.

[20] E. Garcia-Quismondo, C. Santos, J. Lado, J. Palma, M.A. Anderson, Optimizing the Energy Efficiency of Capacitive Deionization Reactors Working under Real-World Conditions, Environmental Science \& Technology, 47 (2013) 11866-11872.

[21] L.Y. Lee, H.Y. Ng, S.L. Ong, G. Tao, K. Kekre, B. Viswanath, W. Lay, H. Seah, Integrated pretreatment with capacitive deionization for reverse osmosis reject recovery from water reclamation plant, Water Research, 43 (2009) 4769-4777.

[22] P. Xu, J.E. Drewes, D. Heil, G. Wang, Treatment of brackish produced water using carbon aerogel-based capacitive deionization technology, Water Research, 42 (2008) 2605-2617.

[23] R.L. Zornitta, J.J. Lado, M.A. Anderson, L.A.M. Ruotolo, Effect of electrode properties and operational parameters on capacitive deionization using low-cost commercial carbons, Separation and Purification Technology, 158 (2016) 39-52. 
[24] J.J. Lado, R.L. Zornitta, F.A. Calvi, M.I. Tejedor-Tejedor, M.A. Anderson, L.A.M. Ruotolo, Study of Sugar Cane Bagasse Fly Ash as Electrode Material for Capacitive Deionization, Journal of Analytical and Applied Pyrolysis, 120 (2016) 389-398.

[25] J.J. Lado, R.E. Pérez-Roa, J.J. Wouters, M. Isabel Tejedor-Tejedor, M.A. Anderson, Evaluation of operational parameters for a capacitive deionization reactor employing asymmetric electrodes, Separation and Purification Technology, 133 (2014) 236-245.

[26] J.J. Lado, R.E. Pérez-Roa, J.J. Wouters, M.I. Tejedor-Tejedor, C. Federspill, M.A. Anderson, Continuous cycling of an asymmetric capacitive deionization system: An evaluation of the electrode performance and stability, Journal of Environmental Chemical Engineering, 3 (2015) 2358-2367.

[27] R. Broseus, J. Cigana, B. Barbeau, C. Daines-Martinez, H. Suty, Removal of total dissolved solids, nitrates and ammonium ions from drinking water using charge-barrier capacitive deionisation, Desalination, 249 (2009) 217-223.

[28] Y.J. Kim, J.H. Kim, J.H. Choi, Selective removal of nitrate ions by controlling the applied current in membrane capacitive deionization (MCDI), J. Membr. Sci., 429 (2013) 52-57.

[29] J.J. Wouters, J.J. Lado, M.I. Tejedor-Tejedor, R. Perez-Roa, M.A. Anderson, Carbon fiber sheets coated with thin-films of $\mathrm{SiO} 2$ and gamma-A12O3 as electrodes in capacitive deionization: Relationship between properties of the oxide films and electrode performance, Electrochimica Acta, 112 (2013) 763-773.

[30] J.J. Wouters, J.J. Lado, M.I. Tejedor-Tejedor, M.A. Anderson, Low Surface Area Carbon Fiber Electrodes Coated with Nanoporous Thin-Films of gamma- $\mathrm{Al}_{2} \mathrm{O}_{3}$ and $\mathrm{SiO}_{2}$ : Relationship between Coating Conditions, Microstructure and Double Layer Capacitance, Journal of The Electrochemical Society, 159 (2012) 1374-1382.

[31] L. Han, K.G. Karthikeyan, M.A. Anderson, J.J. Wouters, K.B. Gregory, Mechanistic insights into the use of oxide nanoparticles coated asymmetric electrodes for capacitive deionization, Electrochimica Acta, 90 (2013) 573-581.

[32] J.J. Lado, J.J. Wouters, M.I. Tejedor-Tejedor, M.A. Anderson, E. García-Calvo, Asymmetric Capacitive Deionization Utilizing Low Surface Area Carbon Electrodes Coated with Nanoporous Thin-Films of $\mathrm{Al}_{2} \mathrm{O}_{3}$ and $\mathrm{SiO}_{2}$, Journal of the Electrochemical Society, 160 (2013) 71-78.

[33] X. Gao, J. Landon, J.K. Neathery, K. Liu, Modification of Carbon Xerogel Electrodes for More Efficient Asymmetric Capacitive Deionization, Journal of the Electrochemical Society, 160 (2013) 106-112.

[34] J.J. Wouters, M.I. Tejedor-Tejedor, J.J. Lado, R. Perez-Roa, M.A. Anderson, Influence of Metal Oxide Coatings on the Microstructural and Electrochemical Properties of Different Carbon Materials, Journal of The Electrochemical Society, 163 (2016) 2733-2744.

[35] E.S. Im, J.-H. Choi, K.Y. Jung, Capacitance Improvement and Electrochemical Characteristics of Silica-Coated Carbon Electrodes for Capacitive Deionization Application, Journal of the Electrochemical Society, 159 (2012) 198-203.

[36] X. Gao, A. Omosebi, J. Landon, K. Liu, Enhancement of Charge Efficiency for a Capacitive Deionization Cell Using Carbon Xerogel with Modified Potential of Zero Charge,

Electrochemistry Communications, (2013).

[37] X. Gao, A. Omosebi, J. Landon, K. Liu, Surface charge enhanced carbon electrodes for stable and efficient capacitive deionization using inverted adsorption-desorption behavior, Energy \& Environmental Science, 8 (2015) 897-909.

[38] X. Gao, S. Porada, A. Omosebi, K. Liu, P. Biesheuvel, J. Landon, Complementary Surface Charge for Enhanced Capacitive Deionization, Water Res., 92 (2016) 275-282.

[39] C.J. Gabelich, T.D. Tran, I.H. Suffet, Electrosorption of inorganic salts from aqueous solution using carbon aerogels, Environmental Science \& Technology, 36 (2002) 3010-3019.

[40] R. Zhao, M. van Soestbergen, H.H.M. Rijnaarts, A. van der Wal, M.Z. Bazant, P.M. Biesheuvel, Time-dependent ion selectivity in capacitive charging of porous electrodes, Journal of Colloid and Interface Science, 384 (2012) 38-44. 
[41] D. He, C.E. Wong, W. Tang, P. Kovalsky, T.D. Waite, Faradaic Reactions in Water Desalination by Batch-Mode Capacitive Deionization, Environmental Science \& Technology Letters, 3 (2016) 222-226.

[42] J.-H. Choi, Determination of the electrode potential causing Faradaic reactions in membrane capacitive deionization, Desalination, 347 (2014) 224-229. 


\section{Proof of Concept}

Three Electrode Cell

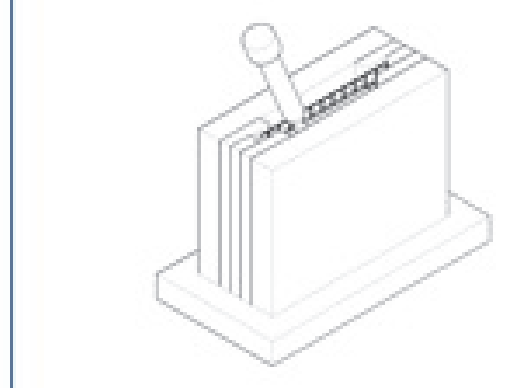

\section{Nitrate Removal}

\section{Proof of Scale-Up}

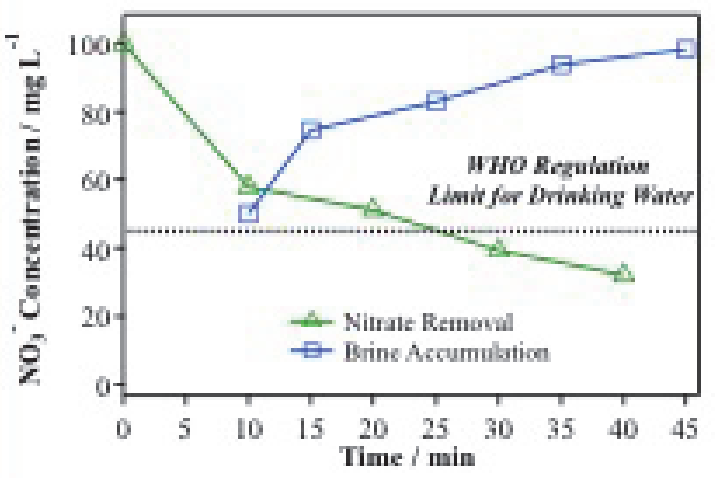

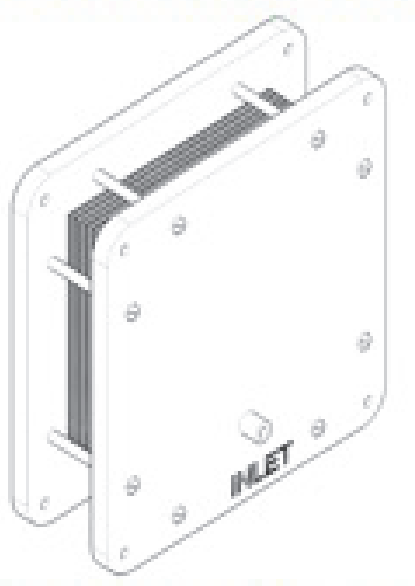

CDI Flow Reactor 